when adding $0.45 \mathrm{p}$ Ioo lysine, which would indicate a lysine requirement of $0.7^{8} \mathrm{p}$. Ioo of the diet. In a second experiment where $0-0.34$ and $0.68 \mathrm{p}$. 100 lysine were added to a diet containing I7 p. Ioo sesame proteins, it was noted that the addition of this amino acid improved the nitrogen balance and nitrogen retention coefficient whereas the digestibility of the diet was not changed.

\title{
EFFECT OF DL-METHIONINE ADDITION TO A SOYBEAN OIL-MEAL DIET ON GROWTH AND NITROGEN RETENTION IN THE RABBIT
}

\author{
M. COLIN, G. ARKHURST \\ avec la collaboration technique de G. SARDI \\ Station de Recherches sur l'Élevage des Porcs, \\ Centre national de Recherches zootechniques, I. N. R. A., \\ 78350 Jouy en Josas
}

It has been demonstrated in the rabbit that DL-Methionine supplementation of soybean oil-meal diets has a favourable effect on growth performances, feed efficiency, nitrogen balance and nitrogen retention coefficient. On the other hand, the digestibility of the diet does not seem to be affected. Using two protein levels (ro and I3 p. Ioo), the best results were obtained with a DL-methionine supplementation of o.I p. Ioo of the diet. But an addition of 0.3 p. Ioo DLmethionine has slight depressive effects on the weight gain. However, on account of the low protein level in the diets studied, it seems to be difficult, on the basis of the present experiment, to make an approach of the requirement for sulphur amino acids in the rabbit.

\section{II. - Pathology}

\section{ROLE OF ESCHERICHIA COLI \\ IN THE AETHIOLOGY OF DIARRHOEA IN THE R.ABBIT}

\author{
L. RENAUlt, J. VAISSAIRE, Cl. MAIRE, E, LE BOURHIS \\ et J. P. LABADIE \\ Laboratoires vétérinaives Sanders, \\ 17. Quai de l'Industrie, \\ 91260 Juvisy sur Orge
}

An experiment carried out on 408 strains of $E$. coli isolated from the intestinal contents of 75 live rabbits, suffering from serious digestive troubles unrelated with coccidiosis showed, through systematic analyses of the hemolytic and pathogenic power on the mouse and enteropa- 
thogenic power on the rabbit, that colibacillosis enteritis exits in this species. Enteropathogenic strains belong to $02,08,020,039$ and 0106 groups in the newborn rabbit and to $02,049,085$, oro3 and or 32 groups in the fattening rabbit.

\title{
IMPORTANCE OF NEPHROPATHIES IN THE RABBIT
}

\author{
J. VAISSAIRE, Cl. MAIRE, L. RENAULT et J. P. LABADIE \\ avec la collaboration technique d'E. Le Bourhis, M. Auvray et C. Pianel \\ Laboratoires vétérinaires Sanders, \\ 17, Quai de l'Industrie, \\ 91260 Juvisy sur Orge
}

Among 669 rabbits received at the laboratory during 1972 about 56 p. roo exhibited nephritis lesions and 60 suffered from " uremic syndrome ". Primary kidney lesions were caused either by microbic or parasitic diseases, or poor management conditions bringing about serious digestive troubles, or, at last, uncontrolled use of medications. Epithelial nephritis bringing about an important mortality by * uremic syndrome ", high levels of urea, reaching in certain cases $4.5 \mathrm{~g}$ per liter of serum, was associated with hyperkaliemia reaching $23 \mathrm{mEq}$ per liter and causing rapid death by heart stopping. To cope with severe nephropathy that may kill up to $50 \mathrm{p}$. Ioo of flocks, farmers should take into consideration the importance of good management practises and good sanitary conditions of their animals.

\section{III. - Physiology}

\section{COMPARISON OF THE HEPRODUCTIVE BEHAVIOUR OF DOES MATED AT DIFFERENT TIME INTERVALS AFTER PARTURITION}

\author{
Maryse SELME et M. PRUD'HON \\ Station de Physiologie animale, I. N.R.A., \\ E. N.S.A., Place Viala, \\ 34060 Montpellier Cedex
}

The effect on ovulation, implantation and embryo survival of the time interval between parturition and mating was studied in 182 primiparous rabbits. The rabbits were mated either on day I (lot I) or on day Io (lot Io) and killed on day IO, I6, 20, 24 or 28 post-coitus. The frequencies of ovulation and implantation were determined, the numbers of corpora lutea (C. L.) 